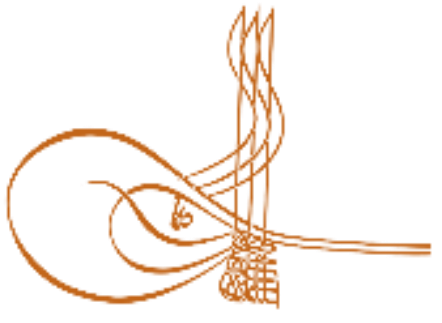

www.turkishstudies.net/social
Turkish Studies - Social Sciences

eISSN: $2667-5617$

Research Article / Araşttrma Makalesi

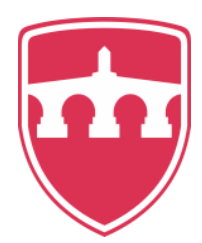

INTERNATIONAL

BALKAN

UNIVERSITY

Sponsored by IBU

\title{
Ortaokul Öğrencilerinin Saldırganlık Eğilimleri ile Okul İklimi Algılarının Çeşitli Değişkenlere Göre İncelenmesi*
}

\author{
Examination of Aggression Tendencies and School Climate Perceptions of Middle School Students \\ According to Various Variables: Example of Kucukcekmece
}

\author{
Burak Küsmez $^{* *}$ - Emel Yeşilkayalı ${ }^{* * *}$
}

\begin{abstract}
Aggressive behaviour has been the subject of scientific researches for years. Aggression behaviours, especially in schools, may cause many problems. Students' negative perceptions of the school climate are one of the main reasons for aggressive behaviours displayed in schools. In this research, the methods of the "school social work", the specialized field of the social work profession, which includes methods on these two topics, are included. The aim of the study is to understand how students' tendencies of aggression and perceptions of school climate are affected by various variables. Within the scope of the research, 1.334 students who studied in Kucukcekmece district and determined using a disproportionate stratified sampling method were examined. Result of the study revealed that students' aggression tendencies differ according to socio-economic circumstance of the region where the school is located, class level, parental marital status, parental education level, income status, the presence of chronic diseases in the household, migration status, television watching time, type of tv series watched, social media usage time, computer game playing and engaging in other game types. Result of the study revealed that school climate perceptions of students differ according to socioeconomic circumstance of the region where the school is located, parental marital status, the presence of working individuals in the household, parental education level, income status, the presence of chronic diseases in the household, migration status, social media usage time, computer game playing and engaging in other game types.
\end{abstract}

\footnotetext{
* Bu çalışma "Ortaokul Öğrencilerinin Saldırganlık Eğilimleri ile Okul İklimi Algıları Arasındaki İlişkinin İncelenmesi: Küçükçekmece Örneği” başlıklı yüksek lisans tezinden üretilmiştir.

** Arş. Gör., Yalova Üniversitesi, Yalova İktisadi ve İdari Bilimler Fakültesi, Sosyal Hizmet

Res. Asst., Yalova University, Yalova Faculty of Economics and Administrative Sciences, Department of Social Services ORCID 0000-0001-8914-5801

burakkusmez94@gmail.com

**** Doç. Dr., İstanbul Sabahattin Zaim Üniversitesi Sağlık Bilimleri Fakültesi, Sosyal Hizmet

Assoc. Prof. Dr. Istanbul Sabahattin Zaim University, Faculty of Health Sciences, Department of Social Services ORCID 0000-0003-2616-2641

emel.yesilkayali@izu.edu.tr

Cite as/ Atıf: Küsmez, B., Yeşilkayalı, E. (2020). Ortaokul öğrencilerinin saldırganlık eğilimleri ile okul iklimi algılarının çeşitli değişkenlere göre incelenmesi, Turkish Studies - Social, 15(1), 435-455. https://dx.doi.org/10.29228/TurkishStudies.40238

Received/Geliş: 19 December/Aralık 2019

Accepted/Kabul: 25 February/Şubat 2020

Copyright $(C)$ INTAC LTD, Turkey

Checked by plagiarism software

Published/Yayın: 29 February/Şubat 2020

CC BY-NC 4.0
} 
Structured Abstract: Aggressive behavior has been the subject of scientific researches for years. Aggression behaviors, especially in schools, may cause many problems. Students' negative perceptions of the school climate are one of the main reasons for aggressive behaviors displayed in schools. The methods of "school social work", which is the specialized field of social work profession in schools are mainly engaged these two subjects.

The fact that aggression is a part of human nature is one of the major factors in the investigation of aggression. Understanding the nature of aggressive behavior, which can be regarded as the source of endless violence, crimes and unwanted behavior might be an important milestone in eliminating existing problems.

The climate of the school has a significant impact on students' positive experience in life. In order to reduce school aggression and violence, the school climate should be improved positively (Brookmeyer, Fanti and Henrich, 2006: 506).

The interest in aggression and violent behaviors has increased since the 1980s. As a result of increasing interest in some European countries and America continental, school aggression became a popular subject of researches frequently (Lopez, et al., 2008: 434).

School social work has a significant impact on identifying risks and protective factors related to aggressive behavior in schools (Powell and Jenson, 2010: 210). Social workers in school play a critical role in eliminating the problem of aggression. They ensure that all staff members are responsible for the coordination and take responsibility for overcoming the aggression problem (Dailey, Frey and Walker, 2015: 85). School social work also has a significant impact on improving school climate. School social work analyzes existing systems for performing multiple interventions and ultimately develops ways to improve the school climate by identifying how students will remain strong in the face of problems (O’Brien, et al., 2011: 97).

The aim of the study is to understand how students' tendencies of aggression and perceptions of school climate are affected by various variables. In this research, general screening method which is one of the quantitative research methods, was used. The universe of the study consisted of 50.000 students enrolled in secondary schools in the district of Kücükcekmece / Istanbul. The sample consists of 1.334 students which were selected from 50.000 students. The non-proportional stratified sampling method was used to determine the sample. The "Aggression Scale" developed by Buss-Perry (1992) and adapted to the Turkish language by Demirtas-Madran (2013), the "School Climate Scale" developed by Calik-Kurt (2010) and developed by the researcher "Personal Information Form" were used to collect the data. For the analysis of the collected data from research, independent t-test and one-way analysis of variance (ANOVA) were used. In addition, Scheffe test was used to determine whether there was a significant difference between the groups.

Results of the study show that middle school students who were enrolled in different schools in Küçükçekmece district were moderate aggressive and their perceived school climate is well. Results also show that there is a negative correlation between students' aggression tendencies and school climate perceptions. Results of the study revealed that, students' aggression tendencies differ according to socio-economic circumstance of the region where the school is located, class level, parental marital status, parental education level, income status, the presence of chronic diseases in the household, migration status, television watching time, type of tv series watched, social media usage time, computer game playing and engaging in other game stypes. Result of the study revealed that, school climate perceptions of students differ according to to socioeconomic circumstance of the region where the school is located, parental marital status, the presence of working individuals in the household, parental education level, income status, the presence of chronic diseases in the household, migration status, social media usage time, compuer game playing and engaging in other game types.

As it is generally accepted in the solution of all student problems, teamwork and a holistic approach are required to decrease the aggression level of the students / channel them in a positive direction and increase the positive perception levels of the school climate. This acceptance requires an ecological perspective on student issues and approaches and solutions not only at school and at the individual level with the student but also at the family, school, class, friends, school environment and community level. This necessity necessitates the implementation of school social work practices in which this perspective is adopted.

In this context, the results of this research need to be evaluated holistically from micro, mezzo and macro intervention levels from an ecological point of view. 
Professional studies should be carried out at students and families at the level of aggressive students and at the same time training should be organized for teachers and school staff in order to increase the positive perception of the classroom and school climate. Socio-cultural and sportive activities and diversity in these activities are also important in perceiving school climate positively. In addition, it is thought that socio-cultural and sporting activities will channel the aggression of the students in a positive direction and enable the students to spend more quality time with their friends.

The importance of establishing a healthy parent and child relationship in schools should be emphasized and parent seminars should be organized on this subject.

Investigations should also be carried out in different dimensions of aggression and school climate and with qualitative research methods.

Keywords: Social work, aggression, school climate, school social work.

Öz: Saldırganlık davranışı yıllardır araştırmalara konu olmaktadır. Özellikle okullarda gerçekleşen saldırganlık davranışları birçok sorunu beraberinde getirebilmektedir. Öğrencilerin okul iklimini olumsuz algılamaları, okullarda sergilenen saldırganlık davranışlarının en büyük nedenlerinden biridir. Bu iki konuya dair yöntemleri barındıran, sosyal hizmet mesleğinin okullarda özelleşmiş alanı "okul sosyal hizmetinin" yöntemlerine bu araştırmada yer verilmiştir. Bu araştırmanın amacı, öğrencilerin saldırganlık eğilimleri ile okul iklimi algılarının çeşitli değişkenlerden nasıl etkilendiğini anlamaktır. Araştırma kapsamında Küçükçekmece ilçesinde öğrenim gören ve orantısız tabakalı örneklem metodu kullanılarak belirlenen 1.334 öğrenci incelenmiştir. Verilerin toplanmasında Buss-Perry (1992) tarafından geliştirilen ve Demirtaş-Madran (2013) tarafından Türkçe diline uyarlanan "Saldırganlık Ölçeği”, Çalık ve Kurt (2010) tarafindan geliştirilen "Okul İklimi Ölçeği” ve yazar tarafindan oluşturulan "Kişisel Bilgi Formu” kullanılmıştır. Araştırma sonucunda; öğrencilerin saldırganlık eğilimlerinin okulun bulunduğu bölgenin sosyo-ekonomik durumuna, sınıf düzeyine, ebeveyn medeni durumuna, ebeveyn eğitim düzeyine, gelir durumuna, hanede kronik hasta bulunma durumuna, göç durumuna, televizyon izleme sürelerine, izlenilen dizi türüne, sosyal medya kullanım süresine, bilgisayar oyunu oynama durumuna ve oyun türüne göre farklılaştı̆̆ı saptanmıştır. Öğrencilerin okul iklimi algilarının ise; okulun bulunduğu bölgenin sosyo-ekonomik durumuna, ebeveynlerin medeni durumuna, hanede çalışan birey bulunma duruma, ebeveyn eğitim düzeyine, gelir durumuna, hanede kronik hastalık bulunma durumuna, göç durumuna, sosyal medya kullanım süresine, bilgisayar oyunu oynama durumuna ve oyun türüne göre farklılaştı̆̆

Anahtar Kelimeler: Sosyal hizmet, saldırganlık, okul iklimi, okul sosyal hizmeti.

\section{Giriş}

Saldırganlık, eski çağlardan beri evrimsel olarak var olan bir davranış biçimidir. Bununla birlikte teorisyenler tarafından çeşitli şekillerde açıklanmış ve bu değerlendirmelere göre çeşitli tanımlamalar yapılmıştır. Saldırganlı̆̆ı açıklamaya yönelik çalışmalar genel olarak saldırganlığın kaynağını belirlemeye odaklanmıştır.

Saldırganlık, önceleri içgüdüsel ve gerekli bir davranış biçimi olarak Lorenz (1966: 5) değerlendirilmiş, Freud (1966: 20), da Eros ve Thanatos ismini verdiği iki egonun çatışmasının sonucu olarak saldırganlığın oluştuğunu ileri sürmüş̧ür. Bu görüşten etkilenen diğer yazarlar saldırganlığın "engellenme" sonucu oluştuğunu iddia etmişlerdir (Dollard, vd., 1939: 12; Durban ve Bowlby, 1939: 24). Fromm (1973: 237-242), ise saldırganlığın bir heyecan yaratma isteği sonucu oluştuğunu savunmuştur. Ancak Bandura (1977: 63), "sosyal öğrenme kuramı" adını verdiği görüşüyle, saldırganlığın içgüdüsel ve tecrübe yoluyla öğrenildiğini ortaya sürmüştür. Bu görüşün etkisiyle saldırganlık ve etkilendiği faktörler araştırmalara sıkça konu olur hale gelmiştir. Her ne kadar çeşitli görüşlerin sonucu olarak farklı tanımlansa da en genel şekliyle saldırganlık "başka bir bireye zarar verme amaçlı sergilenen davranış" (Archer, 2009: 249) olarak tanımlanabilir. Saldırganlık, sergilenme biçimine bağlı olarak da sınıflamaya tabii tutulmuştur. Saldırganlık, 
fiziksel, sözel, araçsal ve düşmanca saldırganlık olarak dört kategoriye ayrılmıştır (Moeller, 2001: 32). Bu doğrultuda bu araştırmada da saldırganlığı ölçmek için fiziksel, sözel, düşmanlık ve öfke boyutu olan bir saldırganlık ölçeği kullanılmıştır (Demirtaş-Madran, 2013: 2).

Araştırma kapsamında ele alınan bir diğer konu okul iklimidir. Okul iklimi, öğrencilerin, velilerinin ve okul personellerinin okul hayatını nasıl tecrübe ettiklerine dayanır ve okulun sahip olduğu tüm formel ve informel özellikleri yansıtır. Okul ikliminin olumlu olması, öğrencilerin olumlu bir gelişim göstermelerini ve topluma katkı sunan bir gençliğin oluşmasını sağlar (NSCC [National School Climate Center], 2014). Okul iklimi, samimi ve içten ilişkilerin bulunduğu açık iklim (Hoy, vd., 1996: 42), tersi ilişkilerin bulunduğu kapalı iklim (Hoy ve Miskel, 1987: 22), öğretmenlerin kolektif çalıştığ 1 bağlı iklim (Hoy, vd., 1996: 52) ve tersi bir durumun bulunduğu çözülmüş iklim (Hoy, vd., 1998: 338) olarak dört şekilde değerlendirilebilir. Bu doğrultuda bu araştırmada da okul iklimi algısını ölçmek için "destekleyici öğretmen davranışları, başarı odaklılık ve güvenli öğrenme ortamı" boyutları olan bir okul iklimi ölçeği kullanılmıştır (Çalık ve Kurt, 2010: 175).

Araştırmadan elde edilen sonuçlar değerlendirilirken "okul sosyal hizmetinin" yaklaşımları ve yöntemleri dikkate alınmıştır. Sosyal hizmet mesleğinin okullarda kullanılmasına dayanan ve bu yüzden okul sosyal hizmeti olarak anılan bu alan (School Social Work Association of America [SSWAA], 2012), saldırgan davranışları önleme ve kontrol altına alma ve olumlu okul iklimi algısı oluşturma ile ilgili çeşitli müdahale yöntemlerini de içinde barındırmaktadır.

$\mathrm{Bu}$ araştırmanın genel amacı öğrencilerin saldırganlık eğilimleri ile okul iklimi algılarının çeşitli değişkenlerden nasıl etkilendiğini ortaya koymaktır. Bu genel amaç çerçevesinde şu soruya yanıt aranmıştır: Öğrencilerin saldırganlık ve okul iklimi alt ölçek puanları; sosyo-ekonomik düzey, cinsiyet, sınıf düzeyi, kardeş sayısı, ebeveynin medeni durumu, hanede çalışan birey sayısı, annebaba eğitim düzeyi, konut, gelir durumu, hanede kronik rahatsızlık, engelli birey bulunma, göçle gelme, televizyon izleme süresi, izlenen dizi türü, sosyal medya kullanma süresi, bilgisayarda oyun oynama süresi ve oynanan oyunun türü açısından gruplar arasında anlamlı farklılık göstermekte midir?

\section{Yöntem}

$\mathrm{Bu}$ araştırmada öğrencilerin saldırganlık eğilimleri ile okul iklimi algılarının çeşitli değişkenlere göre nasıl farklılaştığı araştırılmıştır. Evren hakkında genel bir kanıya varmak ve deneklerin ilgili konulardaki özelliklerinin çeşitli değişkenlere göre tespit etme amacıyla yapılan bu araştırmada nicel araştırma yöntemlerinden genel tarama yöntemi (Gürbüz ve Şahin, 2018: 107) kullanılmıştır.

\section{Evren ve Örneklem}

Araştırmanın evrenini İstanbul ili Küçükçekmece ilçesinde öğrenim gören ortaokul öğrencileri oluşturmaktadır. İlçe Milli eğitim Müdürlüğü verilerine göre, İlçedeki ortaokul öğrenci sayısı yaklaşı 50.000 'dir. Buna göre 50.000 kişilik bir evrenden \%99 doğruluk payında seçilmesi gereken en az örneklem sayısı 657'dir (Gürbüz ve Şahin, 2018). Evren düşük-orta-yüksek tabaka olarak üçe ayrılmış ve örneklemin belirlenmesinde tabakaların evren içindeki oranlarından bağımsız olarak gerçekleştirilen ve tabakalardan eşit ya da farklı olarak seçim yapılan "orantısız tabakalı örneklem" yöntemi kullanılmıştır (Sencer ve Sencer, 1978: 470). Tabakaların belirlenmesinde "Mahallem İstanbul" isimli projenin verilerinden faydalanılmıştır (Mahallem İstanbul, 2018). Bu araştırma kapsamında araştırmaya dahil edilen örneklem sayıs1 1.334'tür. 


\section{Veri Toplama Araçları}

Araştırma kapsamında öğrencilerin saldırganlık düzeylerini ölçmek için Buss ve Perry (1992) tarafından geliştirilen ve Demirtaş-Madran (2013) tarafından uyarlanan 29 maddeden oluşan, 5 aralıklı Likert tipi, fiziksel saldırganlık, sözel saldırganlık, düşmanlık ve öfke olmak üzere saldırganlık davranışının dört farklı boyutunu içeren "Saldırganlık Ölçeği”"; okul iklimi algılarını ölçmek için Çalık ve Kurt (2010) tarafindan geliştirilen, 22 maddeden oluşan, 5 aralıklı Likert tipi, destekleyici öğretmen davranışları, başarı odaklılık ve güvenli öğrenme ortamı olmak üzere üç faktörden oluşan "Okul İklimi Ölçeği" ve demografik bilgiler ile çeşitli bilgileri edinmek için de araştırmacı tarafından oluşturulan "Kişisel Bilgi Formu" kullanılmıştır. Ölçeklerin kullanımı için geliştiren kişilerden gerekli izinler alınmıştır.

Saldırganlık ölçeğinin geçerlik-güvenirlik incelemesi yapılmıştır. İnceleme sonucunda: Fiziksel saldırganlık ölçeğinin Cronbach alpha değeri .76, öfke ölçeğinin Cronbach alpha değeri .57, düşmanlık ölçeğinin Cronbach alpha değeri .64, sözel saldırganlık ölçeğinin Cronbach alphadeğeri .54 , toplam saldırganlık ölçeğinin Cronbach alpha değeri .86 olarak bulunmuştur.

Okul iklimi ölçeğinin geçerlik-güvenirlik incelemesi yapılmıştır. İnceleme sonucunda: Destekleyici öğretmen davranışları ölçeğinin Cronbach alpha değeri; .81, başarı odaklılık ölçeğinin Cronbach alpha değeri .60, güvenli öğrenme ortamı Cronbach alpha değeri .58, ölçeğin toplam puan Cronbach alpha değeri .71 olarak bulunmuştur.

\section{Verilerin Toplanması}

Veriler etik kurul onayı ile, İstanbul İl Milli Eğitim Müdürlügü̈nden alınan izin ve okullarla yapılan görüşmelerin ardından Şubat-Mart 2019 tarihleri arasında toplanmıştır. Verilerin toplanmasında ilgili soru formları öğretmenlere dağıtılııs, soru formları öğretmenlerin gözetiminde eş zamanlı olarak bir ders saatinde doldurulmuştur.

\section{Verilerin Analizi}

Verilerin analiz edilmesinde SPSS 25.0 (Statistical Package for Social Sciences) Programı kullanılmıştır. Verilerin normal dağılım gösterdiği tespit edildiği için parametrik testler kullanılmıştır. Araştırmada kullanılan ölçeklerden elde edilen puanların iki grup ortalamaları arasındaki farkın anlamlılığı için ilişkisiz $\mathrm{t}$ testi, ikiden fazla değişken ortalamaları arasındaki farkın anlamlılığı içinde tek yönlü varyans analizi (Anova) kullanılmıştır. Ayrıca gruplar arasında anlamlı farklılığın olup olmadığını anlamak için Scheffe testi kullanılmıştır.

\section{Araştırma Bulguları}

Araştırmadan elde edilen bulgular, amaç kısmındaki sıraya uygun şekliyle aktarılmıştır.

\section{Göre İncelenmesi}

Öğrencilerin Saldırganlık Düzeyleri ile Okul İklimi Algılarının Çeşitli Değişkenlere

Öğrencilerin saldırganlık ve okul iklimi ölçeği puanlarının sosyo-demografik özelliklerine gruplar arasında anlamlı farklılık gösterip göstermediğine ilişkin sonuçlara Tablo 1'de yer verilmişstir. 
Tablo 1: Öğrencilerin Saldırganlık ve Okul İklimi Ölçeği Puanlarının Sosyo-Demografik Düzeye Göre t Testi Sonuçları

\begin{tabular}{|c|c|c|c|c|c|c|}
\hline Cinsiyet & & $\mathbf{N}$ & $\overline{\mathbf{X}} \pm \mathbf{S}$ & sd & $\mathbf{t}$ & $\mathbf{P}$ \\
\hline \multirow[t]{2}{*}{ Saldırganlık } & Kadın & 635 & $53,23 \pm 18,15$ & 1262 & ,97 & ,922 \\
\hline & Erkek & 629 & $53,33 \pm 17,48$ & & & \\
\hline \multirow[t]{2}{*}{ Okul İklimi } & Kadın & 647 & $70,74 \pm 10,83$ & 1283 & ,88 & ,376 \\
\hline & Erkek & 638 & $71,29 \pm 11,49$ & & & \\
\hline Sinıf düzeyi & & $\mathbf{N}$ & $\overline{\mathbf{X}} \pm \mathbf{S}$ & sd & $\mathbf{t}$ & p \\
\hline \multirow[t]{2}{*}{ Saldırganlık } & 7. sinif & 701 & $51,80 \pm 17,24$ & 1264 & 3,26 & ,001 \\
\hline & 8. sinif & 565 & $55,08 \pm 18,33$ & & & \\
\hline \multirow[t]{2}{*}{ Okul İklimi } & 7. sinif & 708 & $71,16 \pm 10,92$ & 1285 & ,485 & 628 \\
\hline & 8. sinif & 579 & $70,86 \pm 11,44$ & & & \\
\hline Medeni Durum & & $\mathbf{N}$ & $\overline{\mathbf{X}} \pm \mathbf{S}$ & sd & $\mathbf{t}$ & p \\
\hline \multirow[t]{2}{*}{ Saldırganlık } & Evli & 1194 & $52,84 \pm 17,67$ & 1262 & 3,26 & ,001 \\
\hline & Boşanmış & 70 & $60,27 \pm 18,81$ & & & \\
\hline \multirow[t]{2}{*}{ Okul Îklimi } & Evli & 1215 & $71,17 \pm 11,16$ & 1284 & 1,99 & ,045 \\
\hline & Boşanmış & 71 & $68,57 \pm 10,97$ & & & \\
\hline Hanede çalışan & & $\mathbf{N}$ & $\overline{\mathbf{X}} \pm \mathbf{S}$ & sd & $\mathbf{t}$ & $\mathbf{p}$ \\
\hline \multirow{2}{*}{ Saldırganlık } & Var & 1221 & $53,34 \pm 17,84$ & 1264 & ,795 & ,427 \\
\hline & Yok & 45 & $51,20 \pm 16,91$ & & & \\
\hline \multirow[t]{2}{*}{ Okul İklimi } & Var & 1240 & $71,17 \pm 11,12$ & 1285 & 2,36 & ,011 \\
\hline & Yok & 47 & $67,12 \pm 11,54$ & & & \\
\hline \multicolumn{2}{|c|}{ Kronik Rahatsızlık } & $\mathbf{N}$ & $\overline{\mathbf{X}} \pm \mathbf{S}$ & sd & $\mathbf{t}$ & $\mathbf{p}$ \\
\hline \multirow[t]{2}{*}{ Saldırganlık } & Var & 309 & $55,63 \pm 17,81$ & 1262 & 2,67 & ,008 \\
\hline & Yok & 955 & $52,52 \pm 17,74$ & & & \\
\hline \multirow[t]{2}{*}{ Okul İklimi } & Var & 312 & $72,86 \pm 10,94$ & 1282 & 3,36 & ,001 \\
\hline & Yok & 972 & $70,43 \pm 11,17$ & & & \\
\hline \multirow{3}{*}{$\begin{array}{l}\text { Engelli var mı? } \\
\text { Saldırganlık }\end{array}$} & & $\mathbf{N}$ & $\overline{\mathbf{X}} \pm \mathbf{S}$ & sd & $\mathbf{t}$ & $\mathbf{p}$ \\
\hline & Var & 49 & $50,57 \pm 18,09$ & 1263 & 1,08 & 278 \\
\hline & Yok & 1216 & $53,38 \pm 17,80$ & & & \\
\hline \multirow[t]{2}{*}{ Okul İklimi } & Var & 48 & $71,00 \pm 10,41$ & 1284 & ,022 & 993 \\
\hline & Yok & 1238 & $71,03 \pm 11,19$ & & & \\
\hline Göçle gelme & & $\mathbf{N}$ & $\overline{\mathbf{X}} \pm \mathbf{S}$ & sd & $\mathbf{t}$ & $\mathbf{p}$ \\
\hline \multirow[t]{2}{*}{ Saldırganlık } & Evet & 255 & $52,31 \pm 16,10$ & 1262 & ,952 & 341 \\
\hline & Hayır & 1009 & $53,50 \pm 18,22$ & & & \\
\hline \multirow[t]{2}{*}{ Okul İklimi } & Evet & 254 & $72,43 \pm 11,18$ & 1283 & 2,27 & ,028 \\
\hline & Hayır & 1031 & $70,66 \pm 11,13$ & & & \\
\hline \multicolumn{2}{|c|}{ Bilgisayar Oyunu } & $\mathbf{N}$ & $\overline{\mathbf{X}} \pm \mathbf{S}$ & sd & $\mathbf{t}$ & $\mathbf{p}$ \\
\hline \multirow[t]{2}{*}{ Saldırganlık } & Evet & 797 & $55,14 \pm 17,94$ & 1261 & 4,88 & ,000 \\
\hline & Hayır & 466 & $50,11 \pm 17,12$ & & & \\
\hline \multirow[t]{2}{*}{ Okul İklimi } & Evet & 804 & $70,35 \pm 11,31$ & 1284 & 2,84 & ,004 \\
\hline & Hayır & 480 & $72,18 \pm 10,80$ & & & \\
\hline
\end{tabular}

Tablo 1'de görüldüğü gibi öğrencilerin saldırganlık eğilimleri cinsiyete $[\mathrm{t}(1262)=0,97$ $\mathrm{p}>$.05], hanedeki çalışan sayısına [ $\mathrm{t}(1264)=.795, \mathrm{p}>.01]$, hanede engelli birinin bulunma durumuna $[\mathrm{t}(1263)=1,08, \mathrm{p}>.05]$, öğrencilerin göçle gelme durumuna [ $\mathrm{t}(1262)=, 952, \mathrm{p}>.05]$ göre anlaml farkl111klar göstermemektedir.

Benzer şekilde öğrencilerin okul iklimini algılama düzeyleri de cinsiyete $[\mathrm{t}(1283)=0,88 \mathrm{p}>.05]$, sinıf düzeylerine [ $\mathrm{t}(1285)=0485 \mathrm{p}>.05]$, hanede engelli birinin bulunma durumuna göre $[\mathrm{t}(1284)=, 022, \mathrm{p}>.05]$ anlamlı farklılıklar göstermemektedir. 
Tablo 1'de görüldüğü gibi saldırganlık düzeyleri: 8 . sınıf öğrencilerin $(\overline{\mathrm{x}}=55,08)$, 7. sınıflara göre $(\overline{\mathrm{x}}=51,80)$; ebeveyni boşanmış olan öğrencilerin $(\overline{\mathrm{x}}=52,84)$ evli olanlara göre $(\overline{\mathrm{x}}=60,57)$; hanelerinde kronik rahatsızlığ 1 bulunan öğrencilerin $(\overline{\mathrm{x}}=55,63)$, kronik rahatsızlığı olmayan öğrencilere göre $(\bar{x}=55,52)$, bilgisayar oyunu oynayan öğrencilerin $(\bar{x}=55,14)$, oynamayan öğrencilere göre $(\overline{\mathrm{x}}=50,11)$, istatiksel olarak anlamlı düzeyde daha yüksektir.

Tablo 1'de görüldüğü gibi okul iklimini olumlu algılama düzeyleri: ebeveyni evli olan öğrencilerin $(\overline{\mathrm{x}}=71,17)$, ebeveyni boşanmış olanlara göre $(\overline{\mathrm{x}}=69,57)$; hanelerinde çalışan biri olan öğrencilerin ( $(\bar{x}=71,17)$, hanede çalışan biri olmayan öğrencilere göre $(\bar{x}=67,12)$; hanelerinde kronik rahatsızlığ 1 bulunan öğrencilerin $(\overline{\mathrm{x}}=72,86)$, kronik rahatsızlığ 1 olmayan öğrencilere göre $(\overline{\mathrm{x}}=70,43)$; göçle gelen öğrencilerin $(\bar{x}=72,43)$, göçle gelmeyen öğrencilere göre $(\bar{x}=70,66)$, bilgisayar oyunu oynamayan öğrencilerin $(\overline{\mathrm{x}}=72,18)$, oynayanlara göre $(\overline{\mathrm{x}}=70,35)$, istatistiksel olarak anlamlı düzeyde daha yüksektir.

Öğrencilerin saldırganlık ve okul iklimi ölçeği puanlarının sosyo-ekonomik düzeye göre gruplar arasında anlamlı farklılık gösterip göstermediğine ilişkin analiz sonuçları Tablo 2'de gösterilmiştir.

Tablo 2: Öğrencilerin Saldırganlık ve Okul İklimi Ölçeği Puanlarının Sosyo-Ekonomik Düzeye Göre Tek Yönlü Varyans (ANOVA) Analizi Sonuçları

\begin{tabular}{|c|c|c|c|c|c|c|c|c|c|}
\hline Değiş & kenler & $\mathbf{N}$ & $\overline{\mathbf{X}} \pm \mathbf{S}$ & $\begin{array}{c}\text { Varyansın } \\
\text { Kaynağı }\end{array}$ & $\begin{array}{l}\text { Kareler } \\
\text { toplamı }\end{array}$ & sd & $\begin{array}{l}\text { Kare. } \\
\text { Ortal. }\end{array}$ & f & $\mathbf{P}$ \\
\hline \multirow{3}{*}{$\frac{\bar{t}}{\tilde{W}^{\circ}}$} & Alt & 427 & $50,03 \pm 17.41$ & Gruplararası & 8556,3 & 2 & 4278,174 & & \\
\hline & Orta & 387 & $53,33 \pm 17,16$ & Gruplariçi & 392634,1 & 1263 & 310,874 & 13,76 & ,000 \\
\hline & Üst & 452 & $56,27 \pm 18,23$ & Toplam & 401190,5 & 1265 & & & \\
\hline \multirow{3}{*}{$\frac{\bar{E}}{0}$} & Alt & 441 & $74,01 \pm 11,66$ & Gruplararası & 6588,5 & 2 & 3294,250 & & \\
\hline & Ort & 390 & $70,40 \pm 10,82$ & Gruplariçi & 153617,4 & 1284 & 119,640 & 27,53 & , 000 \\
\hline & Üst & 456 & $68,68 \pm 10,29$ & Toplam & 160205,9 & 1286 & & & \\
\hline
\end{tabular}

Analiz sonuçlarına göre Saldırganlık Ölçeği puanları öğrencilerin sosyo-ekonomik düzeylerine göre anlamlı farkl111klar göstermektedir [f $(2-1263)=13,76, p<.01]$. Öğrencilerin sosyoekonomik düzeyleri artıkça saldırganlık eğilimleri de artmıştır. Gruplar arasında anlamlı bir farklılığın olup olmadığı Scheffe testi ile test edilmiş, sadece orta ve üst sosyo-ekonomik düzeydeki öğrencilerin saldırganlık eğilimlerinin alt sosyo-ekonomik düzeyde olanlardan anlamlı bir şekilde yüksek olduğu görülmüştür.

Analiz sonuçlarına göre Okul iklimi Ölçeği puanları öğrencilerin sosyo-ekonomik düzeylerine göre anlamlı farklılıklar göstermektedir $[\mathrm{f}(2-1284)=27.53 \mathrm{p}<.01]$. Öğrencilerin sosyoekonomik düzeyleri artıkça okul iklimini olumlu algılama eğilimleri azalmaktadır. Gruplar arasında anlamlı bir farklılığın olup olmadığı Scheffe testi ile test edilmiş, sadece alt sosyo ekonomik düzeydeki öğrencilerin orta ve üst sosyo-ekonomik düzeydeki öğrencilere göre okul iklimini daha olumlu algılama eğiliminde oldukları görülmüştür.

Öğrencilerin saldırganlık alt ölçek puanlarının cinsiyete göre gruplar arasında anlamlı farkl11ık gösterip göstermediğine dönük t testi sonuçlarına Tablo 3'de yer verilmiştir. 
Tablo 3: Öğrencilerin Saldırganlık Alt Ölçek Puanlarının Cinsiyete Düzeye Göre t Testi Sonuçları

\begin{tabular}{lllcccc}
\hline \multicolumn{2}{c}{ Cinsiyet } & $\mathbf{N}$ & $\overline{\mathbf{X}} \pm \mathbf{S}$ & $\mathbf{~ S d}$ & $\mathbf{t}$ & $\mathbf{p}$ \\
\hline Fiziksel & Kadın & 655 & $13,17 \pm 7,16$ & 1302 & 4,777 &, 000 \\
saldırganlık & Erkek & 649 & $15,03 \pm 6,93$ & & & \\
\hline Düşmanlık & Kadın & 654 & $17,61 \pm 6,59$ & 1307 & 3,89 &, 000 \\
& Erkek & 655 & $16,23 \pm 6,19$ & & & \\
\hline Öfke & Kadın & 657 & $13,28 \pm 5,13$ & 1313 & 1,58 &, 112 \\
& Erkek & 658 & $12,83 \pm 4,97$ & & 1,51 &, 131 \\
\hline Sözel & Kadın & 653 & $9,15 \pm 3,47$ & 1308 & & \\
saldırganlık & Erkek & 657 & $8,86 \pm 3,58$ & & & \\
\hline
\end{tabular}

Tablo 3'de görüldüğü gibi öğrencilerin fiziksel saldırganlık eğilimleri cinsiyete göre anlamlı farklılıklar göstermektedir [ $\mathrm{t}(1302)=4,77 \mathrm{p}<.01]$. Erkek öğrencilerin fiziksel saldırganlık düzeyleri $(\bar{x}=15,03)$ kadın öğrencilere göre $(\bar{x}=13,17)$ daha yüksektir.

Öğrencilerin düşmanlık eğilimleri cinsiyete göre anlamlı farklılıklar göstermektedir [t (1307) $=3,89 p<.01]$. Kadın öğrencilerin düşmanlık eğilimleri $(\bar{x}=17,61)$ erkek öğrencilere göre $(\bar{x}=16,23)$ daha yüksektir.

Öğrencilerin öfke eğilimleri cinsiyete göre anlamlı farklılıklar göstermemektedir [t (1313) $=1,58 \mathrm{p}>.05]$. Benzer şekilde öğrencilerin sözel saldırganlık düzeyleri de cinsiyete göre anlamlı farkl111klar göstermemektedir [ $\mathrm{t}(1308)=1,51 \mathrm{p}>.05]$.

Öğrencilerin saldırganlık ve okul iklimi ölçeği puanlarının kardeş sayısına göre gruplar arasında anlamlı farklılık gösterip göstermediğine dönük sonuçlara Tablo 4'de yer verilmiştir.

Tablo 4: Öğrencilerin Saldırganlık ve Okul İklimi Ölçeği Puanlarının Kardeş Sayısına Göre Tek Yönlü Varyans (ANOVA) Analizi Sonuçları

\begin{tabular}{|c|c|c|c|c|c|c|c|c|c|}
\hline $\begin{array}{l}\text { Karde } \\
\text { sayı }\end{array}$ & & $\mathbf{N}$ & $\overline{\mathbf{X}} \pm \mathbf{S}$ & $\begin{array}{c}\text { Varyansın } \\
\text { Kaynağı }\end{array}$ & $\begin{array}{l}\text { Kareler } \\
\text { toplamı }\end{array}$ & sd & $\begin{array}{l}\text { Kare. } \\
\text { Ortal. }\end{array}$ & f & p \\
\hline \multirow{3}{*}{ 咅 } & Tek & 85 & $52,36 \pm 17,23$ & Gruplararas! & 135,297 & 2 & 67,6 & & \\
\hline & 2 & 439 & $53,64 \pm 17,55$ & Gruplariçi & 399883,10 & 1255 & 318,6 & ,212 & ,809 \\
\hline & $3+$ & 734 & $53,19 \pm 18,09$ & Toplam & 400018,40 & 1257 & & & \\
\hline \multirow{3}{*}{$\bar{E}$} & Tek & 86 & $69,48 \pm 9,95$ & GruplararasI & 948,34 & 2 & 474,1 & & \\
\hline & 2 & 444 & $70,15 \pm 10,60$ & Gruplarici & 157918,24 & 1276 & 123,7 & 3,83 &, 022 \\
\hline & $3+$ & 749 & $71,76 \pm 11,54$ & Toplam & 158866,59 & 1278 & & & \\
\hline
\end{tabular}

Tablo 4'de görüldüğü gibi Saldırganlık Ölçeği puanları öğrencilerin kardeş sayısına göre anlamlı farkl111klar göstermemektedir [ $\mathrm{f}(2-1255)=.212, \mathrm{p}>.01]$.

Analiz sonuçlarına göre Okul iklimi Ölçeği puanları öğrencilerin kardeş sayılarına göre anlamlı farklılıklar göstermektedir [f $(2-1276)=3,83 \mathrm{p}<.05$ ]. Öğrencilerin kardeş sayıları arttıkça okul iklimini olumlu algılama düzeyleri artmaktadır. Gruplar arasında anlamlı bir farklılığın olup olmadığ Scheffe testi ile test edilmiş sadece üç ve üstü kardeşi olanların okul iklimini olumlu algılamaları iki kardeşi olanlara göre anlamlı şekilde yüksek olduğu gözlenmiştir.

Öğrencilerin saldırganlık ve okul iklimi ölçeği puanlarının annenin eğitim düzeyine göre gruplar arasında anlamlı farklılık gösterip göstermediğine dönük sonuçlara Tablo 5'de yer verilmiştir. 
Tablo 5: Öğrencilerin Saldırganlık ve Okul İklimi Ölçeği Puanlarının Annenin Eğitim Düzeyine Göre Tek Yönlü Varyans (ANOVA) Analizi Sonuçları

\begin{tabular}{|c|c|c|c|c|c|c|c|c|c|}
\hline \multicolumn{2}{|c|}{ Anne Ĕgt. } & $\mathbf{N}$ & $\overline{\mathbf{X}} \pm \mathbf{S}$ & $\begin{array}{c}\text { Varyansın } \\
\text { Kaynağı }\end{array}$ & $\begin{array}{l}\text { Kareler } \\
\text { toplamı }\end{array}$ & sd & \multicolumn{2}{|l|}{ Kare. } & $\mathbf{p}$ \\
\hline \multirow{4}{*}{$\stackrel{+\infty}{\frac{1}{3}}$} & O.D & 123 & $50,60 \pm 18,57$ & Gruplararası & 1204,90 & 3 & 401,635 & & \\
\hline & İ.O. & 748 & $53,33 \pm 17,98$ & Gruplariçi & 39891,7 & 1258 & 317,102 & 1,26 & ,284 \\
\hline & Lise & 244 & $53,67 \pm 17,84$ & Toplam & 40011,6 & 1261 & & & \\
\hline & Üni & 147 & $54,68 \pm 19,09$ & & & & & & \\
\hline \multirow{4}{*}{ 司 } & O.D & 124 & $72,70 \pm 10,24$ & Gruplararası & 2194,506 & 3 & 731,502 & & \\
\hline & İ.O. & 759 & $71,76 \pm 11,58$ & Gruplariçi & 15775,8 & 1278 & 123,455 & 5,92 & ,001 \\
\hline & Lise & 252 & $69,17 \pm 10,69$ & Toplam & 15970,3 & 1281 & & & \\
\hline & Üni & 147 & $69,06 \pm 9,96$ & & & & & & \\
\hline
\end{tabular}

Tablo 5'de görüldüğü gibi saldırganlık Ölçeği puanları öğrencilerin annelerinin eğitim düzeylerine göre anlamlı farkl111klar göstermemektedir [ $\mathrm{f}(3-1258)=1,26, \mathrm{p}>.05]$.

Analiz sonuçlarına göre Okul iklimi Ölçeği puanları öğrencilerin annelerinin eğitim düzeylerine göre anlamlı farkl111klar göstermektedir[f(3-1278)=5,92, $\mathrm{p}<.01]$. Annelerin eğitim düzeyleri arttıkça öğrencilerin okul iklimini olumlu algılama düzeyleri düşmektedir. Gruplar arasında anlamlı bir farklılı̆̆ın olup olmadığı Scheffe testi ile test edilmiş sadece annelerin eğitim düzeyleri; okuryazar olmayanların lise mezunu olanlara göre okuryazar olmayanların lehine olumlu, ilkokul ve ortaokul mezunu olanların lise mezunu olanlara göre ilkokul ve ortaokul mezunu olanların lehine olumlu bulunmuştur.

Öğrencilerin saldırganlık ve okul iklimi ölçeği puanlarının babanın eğitim düzeyine göre gruplar arasında anlamlı farklılık gösterip göstermediğine dönük sonuçlara Tablo 6'da yer verilmiştir.

Tablo 6: Öğrencilerin Saldırganlık ve Okul İklimi Ölçeği Puanlarının Babanın Eğitim Düzeyine Göre Tek Yönlü Varyans (ANOVA) Analizi Sonuçları

\begin{tabular}{|c|c|c|c|c|c|c|c|c|c|}
\hline \multicolumn{2}{|c|}{ Baba Ĕgt. } & \multirow[t]{2}{*}{$\mathbf{N}$} & \multirow[b]{2}{*}{$\overline{\mathbf{X}} \pm \mathbf{S}$} & Varyansın & \multicolumn{2}{|l|}{ Kareler } & \multicolumn{2}{|l|}{ Kare. } & \multirow[b]{2}{*}{$\mathbf{p}$} \\
\hline & & & & Kaynağı & toplamı & sd & Ortal. & f & \\
\hline \multirow{4}{*}{ 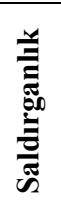 } & O.D & 42 & $50,19 \pm 20,71$ & Gruplararası & 975,536 & 3 & 325,17 & & \\
\hline & İ.o. & 702 & $52,91 \pm 17,68$ & Gruplariçi & 394433,744 & 1248 & 316,053 & 1,02 & ,379 \\
\hline & Lise & 295 & $53,75 \pm 17,73$ & Toplam & 395409,280 & 1251 & & & \\
\hline & Üni & 213 & $54,68 \pm 17,52$ & & & & & & \\
\hline \multirow{4}{*}{ 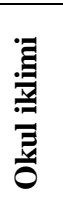 } & O.D & 42 & $70,45 \pm 9,16$ & Gruplararası & 2374,339 & 3 & 791,446 & & \\
\hline & İ.O. & 713 & $72,25 \pm 11,36$ & Gruplariçi & 156675,503 & 1268 & 123,561 & 6,40 & ,000 \\
\hline & Lise & 301 & $69,64 \pm 11,37$ & Toplam & 159049,842 & 1271 & & & \\
\hline & Üni & 216 & $69,22 \pm 10,19$ & & & & & & \\
\hline
\end{tabular}

Tablo 6'da görüldüğü gibi saldırganlık ölçeği puanları öğrencilerin babalarının eğitim düzeylerine göre anlamlı farkl1lıklar göstermemektedir[f(3-1248)=1,029, p >.05].

Analiz sonuçlarına göre Okul iklimi Ölçeği puanları öğrencilerin babalarının eğitim düzeylerine göre anlamlı farklılıklar göstermektedir [f (3-1268) =6,405, p <.01]. Genel olarak babaların eğitim düzeyleri arttıkça öğrencilerin okul iklimini olumlu algılama düzeyleri düşmektedir. Gruplar arasında anlamlı bir farklılığın olup olmadığı Scheffe testi ile test edilmiş sadece babalarının eğitim düzeyleri; ilkokul ve ortaokul mezunu olanların lise ve üniversite mezunu olanlara göre ilkokul ve ortaokul mezunu olanların lehine olumlu bulunmuştur. 
Öğrencilerin saldırganlık ve okul iklimi ölçeği puanlarının konut sahibi olma durumuna göre gruplar arasında anlamlı farklılık gösterip göstermediğine dönük sonuçlara Tablo 7'de yer verilmiştir.

Tablo 7: Öğrencilerin Saldırganlık ve Okul İklimi Ölçeği Puanlarının Konut Durumuna Göre Tek Yönlü Varyans (ANOVA) Analizi Sonuçları

\begin{tabular}{|c|c|c|c|c|c|c|c|c|c|}
\hline Konut & & $\mathbf{N}$ & $\overline{\mathbf{X}} \pm \mathbf{S}$ & $\begin{array}{c}\text { Varyansın } \\
\text { Kaynağı }\end{array}$ & $\begin{array}{l}\text { Kareler } \\
\text { toplamı }\end{array}$ & sd & $\begin{array}{l}\text { Kare. } \\
\text { Ortal. }\end{array}$ & f & $\mathbf{p}$ \\
\hline \multirow{3}{*}{$\frac{\dot{\Xi}}{\frac{\vec{E}}{\hbar n}}$} & Kendi & 788 & $52,82 \pm 17,61$ & \multirow{3}{*}{$\begin{array}{l}\text { Gruplararası } \\
\text { Gruplariçi } \\
\text { Toplam }\end{array}$} & 407,836 & 2 & 203,918 & \multirow{3}{*}{,644 } & \multirow{3}{*}{, 526} \\
\hline & Kira & 450 & $54,01 \pm 18,13$ & & 396627,547 & 1252 & 316,795 & & \\
\hline & Diğer & 17 & $53,29 \pm 17,16$ & & 397035,383 & 1254 & & & \\
\hline \multirow{3}{*}{$\frac{\dot{x}}{\bar{z}}$} & Kendi & 803 & $71,13 \pm 11,32$ & \multirow{3}{*}{$\begin{array}{l}\text { Gruplararası } \\
\text { Gruplariçi } \\
\text { Toplam }\end{array}$} & 584,876 & 2 & 292,438 & \multirow{3}{*}{2,34} & \multirow{3}{*}{,097 } \\
\hline & Kira & 454 & $71,14 \pm 10,81$ & & 158832,348 & 1271 & 124,966 & & \\
\hline & Diğger & 17 & $65,23 \pm 13,56$ & & 159417,224 & 1273 & & & \\
\hline
\end{tabular}

Tablo 7'de görüldüğü gibi Saldırganlık Ölçeği puanları öğrencilerin konuta sahip olma durumuna göre anlamlı farklılıklar göstermemektedir [ $\mathrm{f}(2-1252)=.644, \mathrm{p}>.05]$.

Analiz sonuçlarına göre Okul iklimi Ölçeği puanları öğrencilerin konuta sahip olma durumuna göre anlamlı farkl1lıklar göstermemektedir [f (2-1271) =2,34, p>.05].

Öğrencilerin saldırganlık ve okul iklimi ölçeği puanlarının gelir durumuna göre gruplar arasında anlamlı farklılık gösterip göstermediğine dönük sonuçlara Tablo 8'de yer verilmiştir.

Tablo 8: Öğrencilerin Saldırganlık ve Okul İklimi Ölçeği Puanlarının Gelir Durumuna Göre Tek Yönlü Varyans (ANOVA) Analizi Sonuçları

\begin{tabular}{|c|c|c|c|c|c|c|c|c|c|}
\hline \multicolumn{2}{|c|}{ Gelir } & \multirow[t]{2}{*}{$\mathbf{N}$} & \multirow[b]{2}{*}{$\overline{\mathbf{X}} \pm \mathbf{S}$} & \multirow{2}{*}{$\begin{array}{l}\text { Varyansın } \\
\text { Kaynağı }\end{array}$} & \multirow{2}{*}{$\begin{array}{l}\text { Kareler } \\
\text { toplamı }\end{array}$} & \multirow[b]{2}{*}{ sd } & \multirow{2}{*}{$\begin{array}{l}\text { Kare. } \\
\text { Ortal. }\end{array}$} & \multirow[b]{2}{*}{ f } & \multirow[b]{2}{*}{ p } \\
\hline & & & & & & & & & \\
\hline \multirow{5}{*}{ 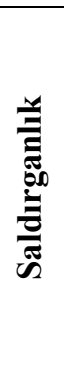 } & 1000 & 74 & $51,59 \pm 18,61$ & Gruplararası & 6501,465 & 4 & 1625,36 & \multirow{5}{*}{5,21} & \multirow{5}{*}{,000 } \\
\hline & 1000- & 184 & $49,91 \pm 17,39$ & Gruplariçi & 37294,74 & 1196 & 311,86 & & \\
\hline & $\begin{array}{l}1500 \\
1501- \\
2000\end{array}$ & 151 & $55,49 \pm 17,88$ & Toplam & 37496,21 & 1200 & & & \\
\hline & $\begin{array}{l}2001- \\
2500\end{array}$ & 208 & $50,99 \pm 17,39$ & & & & & & \\
\hline & $\begin{array}{l}2501 \\
+\end{array}$ & 584 & $55,33 \pm 17,65$ & & & & & & \\
\hline \multirow{5}{*}{ 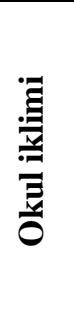 } & 1000 & 76 & $70,76 \pm 11,44$ & Gruplararası & 2093,487 & 4 & 523,372 & \multirow{5}{*}{4,22} & \multirow{5}{*}{,002 } \\
\hline & 1000- & 187 & $72,58 \pm 11,47$ & Gruplariçi & 15014,62 & 1213 & 123,755 & & \\
\hline & $\begin{array}{l}1501- \\
2000\end{array}$ & 153 & $72,04 \pm 10,44$ & Toplam & 15208,10 & 1217 & & & \\
\hline & $\begin{array}{l}2001- \\
2500\end{array}$ & 214 & $72,38 \pm 11,88$ & & & & & & \\
\hline & $2501+$ & 588 & $69,66 \pm 10,85$ & & & & & & \\
\hline
\end{tabular}

Tablo 8'de görüldüğü gibi saldırganlık ölçeği puanları öğrencilerin ailelerinin gelir düzeylerine göre anlamlı farkl1lıklar göstermektedir[ $\mathrm{f}(4-1196)=5,21, \mathrm{p}<.01]$. Gruplar arasında anlamlı bir farklılığın olup olmadığ 1 Scheffe testi ile test edilmiş gelir düzeyi 2501 ve üstü olanlarla 1000-1500 TL olanlar arasında gelir düzeyi 2501 ve üstü olanların lehine saldırganlık eğilimleri yüksek bulunmuştur.

Analiz sonuçlarına göre Okul iklimi Ölçeği puanları öğrencilerin gelir düzeylerine göre anlamlı farklılıklar göstermektedir [ $\mathrm{f}(4-1213)=4,22, \mathrm{p}<.01]$. Gruplar arasında anlamlı bir farklılığın 
olup olmadığı Scheffe testi ile test edilmiş okul iklimini algılama durumu gelir düzeyi 1000-1500 TL olanlarla, 2501 ve üstü TL gelire sahip olanlar arasında gelir düzeyi 1000-1500 TL olanların lehine olumlu bulunmuştur.

Öğrencilerin saldırganlık ve okul iklimi ölçeği puanlarının televizyon izleme süresine göre gruplar arasında anlamlı farklılık gösterip göstermediğine dönük sonuçlara Tablo 9'da yer verilmiştir.

Tablo 9: Öğrencilerin Saldırganlık ve Okul İklimi Ölçeği Puanlarının Televizyon İzleme Süresine Göre Tek Yönlü Varyans (ANOVA) Sonuçları

\begin{tabular}{|c|c|c|c|c|c|c|c|c|c|}
\hline \multicolumn{2}{|c|}{$\begin{array}{l}\text { TV } \\
\text { İzleme }\end{array}$} & $\mathbf{N}$ & $\overline{\mathbf{X}} \pm \mathbf{S}$ & $\begin{array}{c}\text { Varyansın } \\
\text { Kaynağı }\end{array}$ & $\begin{array}{l}\text { Kareler } \\
\text { toplamı }\end{array}$ & sd & $\begin{array}{l}\text { Kare. } \\
\text { Ortal. }\end{array}$ & f & p \\
\hline \multirow{5}{*}{ 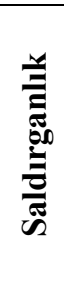 } & 0- & 445 & $53,91 \pm 17,46$ & Gruplararası & 5158,996 & 3 & 1719,66 & & \\
\hline & 1 & & & & & & & & \\
\hline & $\begin{array}{l}2- \\
3\end{array}$ & 439 & $51,56 \pm 17,61$ & Gruplariçi & 39578,612 & 1261 & 314,020 & 5,48 & ,001 \\
\hline & $4-$ & 234 & $52,24 \pm 17,43$ & Toplam & 40137,608 & 1264 & & & \\
\hline & $5+$ & 147 & $58,10 \pm 19,21$ & & & & & & \\
\hline \multirow{5}{*}{ 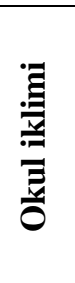 } & 0- & 456 & $70,41 \pm 11,44$ & Gruplararası & 366,637 & 3 & 122,212 & & \\
\hline & 1 & & & & & & & & \\
\hline & $2-$ & 449 & $71,45 \pm 10,92$ & Gruplariçi & 15939,298 & 1281 & 124,777 & ,98 & ,402 \\
\hline & $\begin{array}{l}4- \\
5\end{array}$ & 229 & $70,86 \pm 11,21$ & Toplam & 16005,935 & 1284 & & & \\
\hline & $5+$ & 151 & $71,87 \pm 11,06$ & & & & & & \\
\hline
\end{tabular}

Tablo 9'da görüldüğü gibi saldırganlık ölçeği puanları öğrencilerin televizyon izleme sürelerine göre anlamlı farkl1lıklar göstermektedir [f(3-1261)=5,48, $\mathrm{p}<.01]$. Gruplar arasinda anlamlı bir farklılığın olup olmadığı Scheffe testi ile test edilmiș 5 saat üstü televizyon izleyenlerin saldırganlık eğilimleri, 2-3 saat ve 4-5 saat televizyon izleyenlerden daha yüksek çıktığı görülmüştür.

Öğrencilerin okul iklimini algılama düzeyleri televizyon izleme sürelerine göre anlamlı farkl111klar göstermemektedir [f (3-1281) =,98, p> .05].

Öğrencilerin saldırganlık ve okul iklimi ölçeği puanlarının izlenen dizi türüne göre gruplar arasında anlamlı farklılık gösterip göstermediğine dönük sonuçlara Tablo 10'da yer verilmiştir.

Tablo 10: Öğrencilerin Saldırganlık ve Okul İklimi Ölçeği Puanlarının İzlenen Dizi Türüne Göre Tek Yönlü Varyans (ANOVA) Analizi Sonuçları

\begin{tabular}{|c|c|c|c|c|c|c|c|c|c|}
\hline \multirow{2}{*}{\multicolumn{2}{|c|}{ Dizi Türü }} & \multirow[t]{2}{*}{$\mathbf{N}$} & & \multirow[t]{2}{*}{ V. K. } & \multirow[t]{2}{*}{ K.T. } & \multicolumn{3}{|c|}{ K.O. } & \multirow[b]{2}{*}{ p } \\
\hline & & & $\overline{\mathbf{X}} \pm \mathbf{S}$ & & & sd & & f & \\
\hline \multirow{3}{*}{$\frac{\bar{t}}{\tilde{n}}$} & Aksiyon & 688 & $55,03 \pm 18,16$ & \multirow{3}{*}{$\begin{array}{l}\text { Grup.ara } \\
\text { Grup içi } \\
\text { Toplam }\end{array}$} & 9498,58 & 2 & 4749,2 & & \\
\hline & Komedi & 485 & $49,96 \pm 16,82$ & & 39109,9 & 1253 & 312,08 & 15,22 & , 000 \\
\hline & Dram & 83 & $58,22 \pm 18,26$ & & 40058,5 & 1255 & & & \\
\hline \multirow{3}{*}{$\overline{\bar{z}}$} & Aksiyon & 694 & $70,76 \pm 11,50$ & \multirow{3}{*}{$\begin{array}{l}\text { Grup.ara } \\
\text { Grup içi } \\
\text { Toplam }\end{array}$} & 359,78 & 2 & 179,89 & & \\
\hline & Komedi & 500 & $71,55 \pm 10,78$ & & 15786,0 & 1273 & 124,00 & 1,45 & ,235 \\
\hline & Dram & 82 & $69,57 \pm 9,96$ & & 15215,9 & 1275 & & & \\
\hline
\end{tabular}

Tablo 10'da görüldüğü gibi saldırganlık ölçeği puanları öğrencilerin izlediği dizi türüne göre anlamlı farkl11ıklar göstermektedir [f $(2-1253)=15,22, \mathrm{p}<.01]$. Gruplar arasında anlamlı bir farklılığın olup olmadığ 1 Scheffe testi ile test edilmiş dram izleyen öğrencilerin saldırganlık eğilimlerinin komedi ve aksiyon izleyenlere göre daha yüksek olduğu görülmüştür.

Analiz sonuçlarına göre Okul iklimi Ölçeği puanları öğrencilerin izlediği dizi türüne göre anlamlı farkl11ıklar göstermemektedir [f $(2-1273)=1,45, \mathrm{p}>.05]$. 
Öğrencilerin saldırganlık ve okul iklimi ölçeği puanlarının sosyal medya kullanma sürelerine göre gruplar arasında anlamlı farkl1lık gösterip göstermediğine dönük sonuçlara Tablo 11'de yer verilmiştir.

Tablo 11: Öğrencilerin Saldırganlık ve Okul İklimi Ölçeği Puanlarının Sosyal Medya Kullanma Süresine Göre Tek Yönlü Varyans (ANOVA) Sonuçları

\begin{tabular}{|c|c|c|c|c|c|c|c|c|c|}
\hline \multicolumn{2}{|c|}{$\begin{array}{l}\text { Sosyal } \\
\text { Medya }\end{array}$} & $\mathbf{N}$ & $\overline{\mathbf{X}} \pm \mathbf{S}$ & $\begin{array}{c}\text { Varyansın } \\
\text { Kaynağı }\end{array}$ & $\begin{array}{l}\text { Kareler } \\
\text { toplamı }\end{array}$ & sd & $\begin{array}{l}\text { Kare. } \\
\text { Ortal. }\end{array}$ & f & p \\
\hline \multirow{4}{*}{ 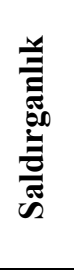 } & 0- & 498 & $49,67 \pm 17,02$ & Gruplararası & 21931,864 & 3 & 7310,62 & & \\
\hline & $\begin{array}{l}1 \\
2- \\
3\end{array}$ & 306 & $51,97 \pm 17,12$ & Gruplariçi & 377528,01 & 1258 & 300,102 & 24,36 & , 000 \\
\hline & $\begin{array}{l}4- \\
5\end{array}$ & 220 & $54,43 \pm 17,05$ & Toplam & 399459,87 & 1261 & & & \\
\hline & $5+$ & 238 & $61,12 \pm 18,40$ & & & & & & \\
\hline \multirow{4}{*}{ 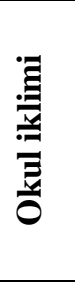 } & 0- & 511 & $72,55 \pm 10,81$ & Gruplararası & 2500,050 & 3 & 833,350 & & \\
\hline & $\begin{array}{l}1 \\
2- \\
3\end{array}$ & 311 & $70,72 \pm 10,49$ & Gruplariçi & 157076,46 & 1279 & 122,812 & 6,786 & ,000 \\
\hline & $\begin{array}{l}4- \\
5\end{array}$ & 221 & $70,22 \pm 11,80$ & Toplam & 159576,51 & 1282 & & & \\
\hline & $5+$ & 240 & $68,85 \pm 11,67$ & & & & & & \\
\hline
\end{tabular}

Tablo 11'de görüldüğü gibi saldırganlık ölçeği puanları öğrencilerin sosyal medya kullanma sürelerine göre anlamlı farklılıklar göstermektedir [f $(3-1258)=24,36, p<.01]$. Öğrencilerin sosyal medya kullanma süresi arttıkça saldırganlık eğilimleri de artmaktadır. Gruplar arasında anlamlı bir farklılığın olup olmadığı Scheffe testi ile test edilmiş 5 saat ve üstü sosyal medya kullanan öğrencilerin 0-1 saat, 2-3 saat ve 4-5 saat kullananlara göre saldırganlık eğilimlerinin daha yüksek çıktığ1 görülmüsşür.

Öğrencilerin okul iklimini algılama düzeyleri sosyal medya kullanma sürelerine göre anlamlı farkl111klar göstermektedir [f(3-1279)=6,78, $\mathrm{p}<.01]$. Öğrencilerin sosyal medya kullanma süresi arttıkça okul iklimini olumlu algılama düzeyleri düşmektedir. Gruplar arasında anlamlı bir farklılığın olup olmadığ 1 Scheffe testi ile test edilmiş sadece 5 saat ve üstü sosyal medya kullanan öğrencilerin 0-1 saat sosyal medya kullananlara göre okul iklimini olumlu algılama eğilimlerinin düşük olduğu görülmüştür.

Öğrencilerin saldırganlık ve okul iklimi ölçeği puanlarının bilgisayarda oynanan oyun türüne göre gruplar arasında anlamlı farklılık gösterip göstermediğine dönük sonuçlara Tablo 12 'de yer verilmiştir.

Tablo 12: Öğrencilerin Saldırganlık ve Okul İklimi Ölçeği Puanlarının Bilgisayarda Oynanan Oyun Türüne Göre Tek Yönlü Varyans (ANOVA) Analizi Sonuçları

\begin{tabular}{|c|c|c|c|c|c|c|c|c|c|}
\hline \multicolumn{2}{|c|}{ Sosyal Medya } & $\mathbf{N}$ & $\overline{\mathbf{X}} \pm \mathbf{S}$ & V.K. & K.T. & sd & K.O. & f & $\mathbf{p}$ \\
\hline \multirow{4}{*}{ 章 } & Aksiyon & 138 & $54,66 \pm 19,50$ & Grup ara. & 4123,919 & 3 & 1374,64 & & \\
\hline & Spor & 89 & $48,98 \pm 17,71$ & Grup içi & 255952,69 & 804 & 318,349 & 4,32 & ,005 \\
\hline & Savaş & 488 & $56,35 \pm 17,37$ & Toplam & 260076,61 & 807 & & & \\
\hline & O.R.Y & 93 & $55,23 \pm 17,82$ & & & & & & \\
\hline \multirow{4}{*}{ 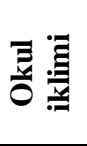 } & Aksiyon & 147 & $72,52 \pm 10,72$ & Grup ara. & 1086,822 & 3 & 362,274 & & \\
\hline & Spor & 94 & $71,44 \pm 11,05$ & Grup içi & 104739,13 & 814 & 128,672 & 2,82 & ,038 \\
\hline & Savaş & 483 & $69,59 \pm 11,63$ & Toplam & 105825,96 & 817 & & & \\
\hline & O.R.Y & 94 & $70,79 \pm 11,07$ & & & & & & \\
\hline
\end{tabular}

Tablo 12'de görüldüğü gibi saldırganlık ölçeği puanları öğrencilerin bilgisayarda oynanan oyun türüne göre anlamlı farklılıklar göstermektedir [f $(3-804)=4,32, \mathrm{p}<.01$ ]. Gruplar arasında anlamlı bir farklılı̆̆ın olup olmadığı Scheffe testi ile test edilmiş sadece bilgisayarda savaş oyunu 
oynayan öğrencilerin spor oyunu oynayanlara göre saldırganlık eğilimlerinin daha yüksek çıktı̆̆ görülmüş̧ür.

Öğrencilerin okul iklimini algılama düzeyleri öğrencilerin bilgisayarda oynanan oyun türüne göre anlamlı farklılıklar göstermektedir [f $(3-814)=2,82, \mathrm{p}<.05]$. Gruplar arasinda anlamlı bir farklılığın olup olmadığı Scheffe testi ile test edilmiş sadece bilgisayarda aksiyon oyunu oynayan öğrencilerin savaş oyunu oynayanlara göre okul iklimini daha olumlu algıladıkları görülmüştür.

\section{Sonuç ve Tartışma}

$\mathrm{Bu}$ araştırma, ortaokul öğrencilerinin saldırganlık eğilimleri ile okul iklimi algılarının çeşitli değişkenlere göre nasıl değiştiğini belirlemek amacıyla gerçekleştirilmiştir.

Öğrencilerin saldırganlık eğilimleri cinsiyete göre istatiksel olarak anlamlı farklılık göstermemekle birlikte, saldırganlığın alt boyutlarından fiziksel saldırganlıkta erkeklerin daha saldırgan olduğu görülmüştür. Erkeklerin fiziksel olarak daha saldırgan olduğunu destekleyen araştırma sonuçları mevcuttur (Fujihara, 1999; Nair, 2014; Matuszka, 2017; Björjkqvist, 2018). Bu durumun, toplumun cinsiyete ilişkin kalıp yargılarında da değişikliğin meydana gelmesinden kaynaklanmış olabileceği düşünülmektedir.

Öğrencilerin saldırganlık eğilimlerinin okulların bulunduğu bölgenin sosyo-ekonomik düzeyine ve ailenin gelir durumuna göre farklılaştığ 1 , sosyo-ekonomik durum ve ailenin geliri yükseldikçe saldırganlık eğiliminin de arttı̆̆ 1 görülmüştür. Bu araştırmanın sonuçları ile benzer olarak sosyo-ekonomik durum arttıkça saldırganlığın da arttığına dair sonuçlar ortaya koyan araştırmaların sayısı oldukça fazladır (Ağlamaz, 2006; Eroğlu, 2009; Gönültaş, 2013; Torun, 2016). Yine Yeşilkayalı (2014) da yaptı̆̆ 1 araştırmada okulların bulunduğu bölgenin sosyo-ekonomik durumunun "şiddetten kaçınma" davranışını etkilediğini saptamıştır. Araştırma kapsamında üst sosyo-ekonomik düzeyde bulunan öğrencilerin genellikle anne ve babalarının da çalıştığı, öğrencilerin genel itibarıyla okul sonrası yaşamlarını, aileleri gelene kadar, yalnız geçirdiği görülmüştür. Yaşanan bu geçici ebeveyn mahrumiyetinin saldırganlığa etki ettiği yorumu yapılabilir.

Öğrencilerin saldırganlık eğilimleri sınıf düzeylerine, ebeveynlerin medeni durumlarına, hanede kronik hastalı̆̆ı olan bireyin bulunma durumuna, televizyon izleme sürelerine, izlenilen dizi türüne, sosyal medya kullanım sürelerine, bilgisayar oyunu oynama durumlarına, oynanılan bilgisayar oyun türüne göre farklılaşmaktadır.

Sınıf düzeyi arttıkça saldırganlık da artmaktadır. Bu araştırma ile aynı sonucun bulunduğu araştırmalar mevcuttur (Yasankul, 2007; Başaran, 2008; İzmir Karaduman, 2012; Aytekin, 2015; Kongur, 2015; Yelci, 2018). Bunun yaş üstünlüğünden ya da sinav stresinden olduğu düşünülebilir. Ebeveynleri boşanmış olan öğrencilerin daha saldırgan oldukları görülmüştür ve böyle öğrencilerin daha saldırgan olduğunu saptayan araştırmaların da sayısı oldukça fazladır (Dizman, 2006; Çelik, 2006; Milan ve Pinderhughes, 2006; Başaran, 2008; Andreas ve Watson, 2009; Gönültaş, 2013; Çetin, 2015). Bu durumun parçalanmış ailenin çocuk üzerinden yarattığı olumsuz etkilerden olduğu söylenebilir. Hanelerinde kronik hastalığı olan birey bulunan öğrencilerin saldırganlık eğilimleri daha yüksektir. İlgili değişkenleri inceleyen ve bu araştırmalar ile benzer sonuçları elde eden araştırmalar mevcuttur (Kurt, 2010; Y1ldırım, vd., 2011; Bayrak, 2011; Taşçı Eser, vd., 2012). Bakım yükü öğrencileri saldırganlığa sevk ediyor olabilir. Öğrencilerin saldırganlık eğilimleri, televizyon izleme sürelerine göre farklılaşmaktadır. Saldırganlık düzeyi en yüksek grubun 5 ve üzeri saat televizyon izleyen grup olduğu saptanmıştır. İlgili değişkenlerin ilişkisini inceleyen ve bu araştırmaya benzer sonuçların elde edildiği araştırmalar alan yazında fazlasıyla mevcuttur (Santisteban, vd., 2007; Sili, 2010; Akçay ve Özcebe, 2012; Öztürk, 2014; Yalçın, 2015). Öğrencilerin televizyona ayırdığı vakitlerin asosyallik yarattığı ve bunun da saldırganlığa sebep olduğu düşünülebilir. Aksiyon ve dram türünde dizi izleyen öğrencilerin saldırganlık düzeyleri birbirine yakın bulunmuş ancak dram türünde dizi izleyen öğrencilerin saldırganlık düzeylerinin en 
yüksek grup olduğu görülmüştür. Alan yazında ilgili ilişkiyi inceleyen araştırmalar da benzer sonuçları bulmuştur. (Bandura, Ross ve Ross, 1961; Lovass, 1961; Walters ve Willows, 1968; Hartmann ve Gelfand, 1969; Sili, 2010; Taylan, 2011; Yalçın, 2015). Sosyal öğrenme kuramının davranış taklidi burada etkili oluyor olabilir. Yapılan analiz sonucunda öğrencilerin sosyal medya kullanım süreleri arttıkça saldırganlık düzeylerinin de arttığı tespit edilmiştir. İlgili değişkenlerin ilişsisini inceleyen ve aynı sonuçları bulan araştırmalar alan yazında mevcuttur (Sili, 2010; İli, 2013; Yalçın, 2015; Durak vd., 2018). Sosyal medyada yer alan olumsuz ögelerin öğrencileri saldırganlık davranışını sergilemeye yönelttiği düşünülebilir. Bilgisayar oyunu oynayan öğrencilerin saldırganlık düzeylerinin oynamayanlara oranla daha yüksek olduğu saptanmıştır. Benzer sonuçların elde edildiği araştırmalara alan yazında rastlamak mümkündür (Bilgi, 2005; Santisteban, vd., 2007; Evcin, 2010; Burak, 2013). Genel olarak spor türü dışındaki oyunları oynayan öğrencilerin saldırganlık düzeylerinin yüksek olduğu ancak en yüksek grubun savaş türü oyun oynayan grup olduğu saptanmıştır. Alan yazında genel olarak şiddet içerikli oyunları oynayan öğrencilerin daha saldırgan olduğunu tespit eden araştırmalar mevcuttur (Bilgi, 2005; Evcin, 2010; Günay, 2011; Burak, 2013; Ergür, 2015; Burak ve Ahmetoğlu, 2015; Çankaya ve Ergin, 2015; Şelimen ve Ceylan, 2018). Son zamanlarda popüler olan oyunların saldırganlık unsurunu oldukça yoğun barındırmasının sonucu olarak öğrencilerin daha saldırgan olması normal olarak değerlendirilebilir.

Öğrencilerin okul iklimi algıları, okulların bulunduğu bölgenin sosyo-demografik düzeyine, ailenin gelir durumuna, kardeş sayılarına, hanelerinde çalışan birey bulunup bulunmama durumuna, anne ve babalarının eğitim düzeylerine, hanede kronik hastalığ göçle gelme durumuna, sosyal medya kullanım sürelerine, bilgisayar oyunu oynama durumlarına, oynanan bilgisayar oyunu türüne göre farklılaşmaktadır.

Sosyo-ekonomik düzey ve gelir düzeyi yükseldikçe öğrencilerin okul iklimini olumlu algılama düzeyleri düşmektedir. Aynı sonuçlar olmasa da benzer sonuçların bulunduğu araştırmalar mevcuttur (Dönmez, 2006; Way, 2007; Akman, 2010; Jia vd., 2016; Dönmez ve Taylı, 2018). Bu durumun velilerin fikirlerinin öğrencileri etkilemesinden kaynaklandığı düşünülebilir. Öğrencilerin kardeş sayıları arttıkça okul iklimini olumlu algılama düzeyleri de artmaktadır. Aynı sonuçlar olmasa da araştırmanın sonucuna benzer olarak, hanedeki birey sayısı, akademik başarı, okul yaşam kalitesi gibi değişkenler ile okul iklimini olumlu algılama arasında ilişkilerin tespit edildiği araştırmalar mevcuttur (Doğan, 2011; Abay ve Keleşoğlu, 2016; Günalan, 2018). Kalabalık ailede yaşamayan öğrencilerin okulda kişisel alan mahrumiyeti yaşadığ 1 düşünülebilir. Hanelerinde çalışan birey bulunan öğrenciler okul iklimini daha olumlu algılamaktadırlar. Öğrencilerin okula katılımları maddi durum ile orantılı olabilmektedir. Annelerin eğitim düzeyi yükseldikçe öğrencilerin okul iklimini daha olumsuz algıladıkları tespit edilmiştir. İlgili değişkenlerin ilişkisini inceleyen ve benzer sonuçlar bulan araştırmalar mevcuttur (Arıman, 2007; Omay, 2008; Dindar, 2008; Saraç, 2015). Baba eğitim durumunda da benzer bir durum söz konusu olup, baba eğitim düzeyi yükseldikçe öğrencilerin okul iklimini olumlu algılama düzeyleri genel olarak düşmüştür. Bu araştırma ile benzer sonuçları tespit eden araştırmalar bulunmaktadır (Omay, 2008; Dindar, 2008; Fan vd., 2011; Saraç, 2015). Anne ve babaların eğitim düzeyi yükseldikçe iş hayatına katılma oranları yükselebilmekte bu da çocukların iş durumlarından dolayı eğitim düzeyine göre algılarının düşmesine sebep olabilir. Hanelerinde kronik hastalığı olan birey bulunan öğrencilerin okul iklimini olumlu algılama düzeyleri daha yüksektir. Öğrenciler bakım yükünden kaçmak için okulu bir sığınak olarak değerlendiriyor olabilirler. Göçle gelen öğrencilerin okul iklimini daha olumlu algıladıkları tespit edilmiştir. $\mathrm{Bu}$ araştırmanın sonucuna benzer bir sonucu Özdemir (2016), yaptığı araştırma sonucunda ortaya koymuştur. Araştırma kapsamında ülkenin doğusundan ve Suriye'den göç eden öğrenciler çoğunluktadır ve şu an ki okullarını eskiye kıyasla daha kaliteli buluyor olabilirler ki bu da göçle gelen öğrencilerin okul iklimini daha olumlu algılamalarında bir etken olabilir. Öğrencilerin sosyal medya kullanım süresi arttıkça, okul iklimini olumlu algılama düzeyleri azalmaktadır. Farklı örneklem grupları ile olsa da okul ikliminin çeşitli unsurlarını barındıran benzer sonuçların 
bulunduğu araştırmalar mevcuttur (Duman, 2008; Aydın, 2011; Akdağ vd., 2014). Öğrencilerin sosyal medya kullanmayı, okuldan daha eğlenceleri bulmaları söz konusu olabilir. Yapılan analize göre bilgisayar oyunu oynayan öğrencilerin okul iklimini olumlu algılama düzeyleri oynamayan öğrencilerden daha düşüktür. Okul ikliminin çeşitli unsurları ile bilgisayar oynama durumu arasında benzer sonuçların tespit edildiği araştırmalar mevcuttur (Aksaçlığlu, 2005; Torun vd., 2015; Elmas, vd., 2015). Savaş türü oyun oynayan öğrencilerin okul iklimini en olumsuz algılayan grup olduğu belirlenmiştir. İlgili değişkenleri direkt olarak inceleyen araştırmalar mevcut olmasa da bu araştırmaya benzer araştırmalar mevcuttur (Altuğ vd., 2011; Çakır, 2013). Bilgisayar oyunu oynama durumu bazen dijital bağımlılığı beraberinde getirebilmekte bu da öğrencilerin temel sorumluluklarını göz ardı etmelerine neden olabilmektedir.

Sonuç olarak, öğrenim görülen okulun genel sosyo-ekonomik düzeyi ve öğrencilerin aile gelir durumu hem saldırganlık düzeyini hem de okul iklimi algısını etkilemektedir. Okulun genel sosyo-ekonomik düzeyi ile öğrencinin aile gelir düzeyi arttıkça, öğrencilerin saldırganlık düzeyi artmakta ve okul iklimini olumlu algılama düzeyi düşmektedir. Ailede kronik hastalığı olan birey bulunan öğrencilerin saldırganlık düzeyi artmakta ancak okul iklimini daha olumlu algılamaktadırlar. Öğrencilerin sosyal medya kullanma süresi arttıkça saldırganlık düzeyi artmakta, okul iklimi algıları düşmektedir. Bilgisayar oyunu oynayan öğrenciler ile bilgisayarda savaş türü oyunlar oynayan öğrencilerin de saldırganlık düzeyleri daha yüksek ve okul iklimini olumlu algılama düzeyleri daha düşüktür.

\section{Öneriler}

Öğrencilerin saldırganlık düzeylerinin azalması/olumlu yöne kanalize edilmesi ve okul iklimini olumlu algılama düzeylerinin arttırılması için, tüm öğrenci sorunlarının çözümünde genel kabul gördüğü gibi, ekip çalışması ve bütüncül ele alış gerekmektedir. Bu kabul, öğrenci sorunlarına ekolojik bir bakış açısı ve sadece okulda ve öğrenci ile bireysel düzeyde değil, aile, okul, sınıf, arkadaşlar, okul çevresi ve toplum düzeyinde yaklaşılmasını ve çözüm üretilmesini gerektirmektedir. $\mathrm{Bu}$ gereklilik ise, bu bakış açısının benimsendiği okul sosyal hizmeti uygulamalarının da hayata geçirilmesini zorunlu kılmaktadır.

Bu bağlamda, bu araştırmanın sonuçlarının, ekolojik bir bakış açısı ile mikro, mezzo ve makro tüm müdahale düzeylerinde ve bütüncül değerlendirilmesi gerekmektedir.

Saldırganlık eğilimi gösteren öğrenciler ile öğrenci ve aile düzeyinde mesleki çalı̧̧malar yapılmalı, aynı zamanda sınıf ve okul iklimini olumlu algılama düzeyini arttırmak için öğretmen ve okul personeli için de eğitimler düzenlenmelidir. Okul iklimini olumlu algılamada sosyo-kültürel ve sportif faaliyetlerin ve bu faaliyetlerde çeşitliliğin sağlanması da önemli bulunmaktadır. Ayrıca sosyo-kültürel ve sportif faaliyetlerin öğrencilerin saldırganlıklarının da olumlu yöne kanalize olmasını, öğrencilerin arkadaşları ile daha kaliteli zaman geçirmesini sağlayacağı düşünülmektedir.

Okullarda sağlıklı ebeveyn ve çocuk ilişkisi kurulmasının önemi üzerinde durulmalı ve bu konuda veli seminerleri düzenlenmelidir.

Saldırganlık ve okul ikliminin farklı boyutlarında ve nitel araştırma yöntemleri ile de araştırmalar gerçekleştirilmelidir.

\section{Kaynakça}

Abay, A. R. ve Keleşoğlu, F. (2016). Okul sosyal hizmeti perspektifinden lise öğrencilerinin akademik başarı düzeylerinin farklı değişkenler açısından incelenmesi. Yalova Sosyal Bilimler Dergisi, 6(11): 9-25. https://doi.org/10.17828/yalovasosbil.286917 
Ağlamaz, T. (2006). Lise öğrencilerinin saldırganlık puanlarının kendini açma davranışı, okul türü, cinsiyet, sınıf düzeyi, anne-baba öğrenim düzeyi ve ailenin aylık gelir düzeyi açısından incelenmesi (Yüksek Lisans Tezi). 19 Mayıs Üniversitesi Sosyal Bilimler Enstitüsü, Samsun.

Akçay, D. ve Özcebe, H. (2012). Televizyonun okul öncesi dönemdeki çocukların saldırganlık davranışına etkisi. Çocuk Sağlı̆̆ı ve Hastalıkları Dergisi, 55(2): 82-87.

Akdağ, M., vd. (2014). Üniversite öğrencilerinin internet bağımlılıklarının çeşitli değişkenler açısından incelenmesi (İnönü Üniversitesi örneği). İnönü Üniversitesi Eğitim Fakültesi Dergisi, 15(1): 73-96. https://doi.org/10.17679/iuefd.98972

Akman, Y. (2010). Illköğretim ikinci kademe ögrencilerinin şiddet ve okul iklimi algıları arasındaki ilişsi (Yüksek Lisans Tezi). Gazi Üniversitesi, Eğitim Bilimleri Enstitüsü, Ankara. https://doi.org/10.1501/egifak_0000000344

Aksaçlığlu, A. G. (2005). Öğrencilerin televizyon izleme ve bilgisayar kullanmalarının okuma alışkanlıkları üzerine etkisi (Yüksek Lisans Tezi). Hacettepe Üniversitesi, Sosyal Bilimler Enstitüsü, Ankara.

Altuğ, M., vd. (2011). Ortaöğretim öğrencilerinin hayatında bilgisayarı yeri. Bilişim Teknolojileri Dergisi, 4(1): 19-27.

Andreas, J. B. ve Watson, M. W. (2009). Moderating effects of family environment on the association between children's aggressive beliefs and their aggression trajectories from childhood to adolescence. Development and Psychopathology, 21(2009): 189-205. https://doi.org/10.1017/s0954579409000121

Arıman, F. (2007). Illköğretim 7. ve 8. sinıf ögrencilerinin zorbalı eğilimleri ile okul iklimi algıları arasındaki ilişkinin incelenmesi (Yüksek Lisans Tezi). Yeditepe Üniversitesi, Sosyal Bilimler Enstitüsü, İstanbul.

Aytekin, E. (2015). Ortaokul öğrencilerinin saldırganlık düzeyinin ebeveyn kabul red algisı ve demografik değişkenlere göre incelenmesi (Yüksek Lisans Tezi). Gazi Üniversitesi, Eğitim Bilimleri Enstitüsü, Ankara.

Bandura, A., Ross, D. Ve Ross, S. A. (1961). Transmission of aggression through 1mitation of aggressive models. Journal of Abnormal and Social Psychology, 63(3): 575-582. https://doi.org/10.1037/h0045925

Bandura, A. (1977). Social learning theory. Englewood Cliffs, NJ: Prentice-Hall.

Başaran, C. (2008). Çeşitli tür liselerde öğrenim gören öğrencilerin saldırganlık düzeylerinin incelenmesi (Yüksek Lisans Tezi). Sakarya Üniversitesi, Sosyal Bilimler Enstitüsü, Sakarya.

Bayrak, B. (2011). 10-12 yaşlarındaki ögrrencilerin saldırganlık eğilimleri ve bunu etkileyen faktörlerin belirlenmesi (Yüksek Lisans Tezi). Hacettepe Üniversitesi, Sağlik Bilimleri Enstitüsü, Ankara.

Bilgi, A. (2005). Bilgisayar oyunu oynayan ve oynamayan ilköğretim ögrencilerinin saldırganlık, depresyon ve yalnızlık düzeylerinin incelenmesi (Yüksek Lisans Tezi). Marmara Üniversitesi, Eğitim Bilimleri Enstitüsü, İstanbul.

Björkqvist, K. (2018). Gender differences in aggression. Current Opinion in Psychology, 19(1): 3942. https://doi.org/10.1016/j.copsyc.2017.03.030

Brookmeyer, K. A., Fanti, K. A. ve Henrich, C. C. (2006). Schools, parents and youth violence: A multilevel ecological analysis. Journal of Clinical Child \& Adolescent Psychology, 35(4): 504-514. https://doi.org/10.1207/s15374424jccp3504_2 
Burak, Y. ve Ahmetoğlu, E. (2015). Bilgisayar oyunlarının çocukların saldırganlık düzeylerine etkisinin incelenmesi. International Periodical fort he Languages, Literature and History of Turkish of Turkic, 10(2015): 363-382. https://doi.org/10.7827/turkishstudies.8430

Buss, D. M. ve Shackelford, T. K. (1997). Human aggression in evolutionary psychological perspective. Clinical Psychology Review, 17(6): 605-619. https://doi.org/10.1016/s02727358(97)00037-8

Çakır, H. (2013). Bilgisayar oyunlarına ilişkin ailelerin görüşleri ve öğrenci üzerindeki etkilerin belirlenmesi. Mersin Üniversitesi Eğitim Fakültesi Dergisi, 9(2): 138-150.

Çalık, T. ve Kurt, T. (2010). Okul iklimi ölçeğinin (oiö) geliştirilmesi. Eğitim ve Bilim, 35(157): 167180.

Çankaya, G. ve Ergin, H. (Mayıs, 2015). Çocukların oynadıkları oyunlara göre empati ve saldırganlık düzeylerinin incelenmesi. Uluslararası Katılımlı III. Çocuk Gelişimi ve Eğitimi Kongresi "Erken Müdahale”. Erişim adresi: https://dergipark.org.tr/download/article-file/88865

Çelik, H. (2006). Üniversite birinci sınıf ögrencilerinin saldırganlık tepkileri, bağlanma tarzları ve kişilerarası şemalarının incelenmesi (Yüksek Lisans Tezi). Marmara Üniversitesi, Eğitim Bilimleri Enstitüsü, İstanbul.

Çetin, B. (2015). Kentte ve kırsalda yetişmiş ortaokul öğrencilerinin benlik saygısı ile saldırganlık düzeylerinin incelenmesi (Yüksek Lisans Tezi). Nişantaşı Üniversitesi, Sosyal Bilimler Enstitüsü, İstanbul.

Dailey, A. L., vd. (2015). Relational aggression in school settings: definition, development, strategies, and 1mplications. Children \& Schools, 37(2): 79-88. https://doi.org/10.1093/cs/cdv003

Demirtaş-Madran, H. A. (2013). Buss-Perry saldırganlık ölçeğinin türkçe formunun geçerlik ve güvenirlik çalışması. Türk Psikiyatri Dergisi, 24(2): 124-129.

Dewitt, P. ve Slade, S. (2014). School climate change: how do a build a positive environment for learning? USA: ASCD Printing.

Dindar, M. M. (2008). Farklı türdeki ortaöğretim kurumlarında öğrenim gören öğrencilerin okul iklimi algılarının karşılaştırılması (Yüksek Lisans Tezi). Yeditepe Üniversitesi, Sosyal Bilimler Enstitüsü, İstanbul.

Dizman, H. (2003). Anne-babası ile yaşayan ve anne yoksunu olan çocukların saldırganlık eğilimlerinin incelenmesi (Yüksek Lisans Tezi). Ankara Üniversitesi, Fen Bilimleri Enstitüsü, Ankara.

Doğan, S. (2011). Genel lise öğrencilerinin algılarına göre okul tahripçiliği ile okul iklimi arasındaki ilişski (Doktora Tezi). Gazi Üniversitesi, Eğitim Bilimleri Enstitüsü, Ankara.

Dollard, J., vd. (1939). Frustration and aggression, (7th ed.). New Haven: Yale University Press.

Dönmez, Ş. (2006). Ortaokul ögrencilerinde okul iklimi, okula bağlllık ve okul yaşam kalitesi algısının çeşitli değişkenler açısından incelenmesi (Yüksek Lisans Tezi). Muğla Sitkı Koçman Üniversitesi, Eğitim Bilimleri Enstitüsü, Muğla.

Dönmez, Ş. ve Taylı, A. (2018). Ortaokul öğrencilerinde okul iklimi, okula bağl1lık ve okul yaşam kalitesi algısının incelenmesi. Adnan Menderes Üniversitesi Eğitim Fakültesi Eğitim Bilimleri Dergisi, 9(2): 1-17. 
Duman, G. K. (2008). İlköğretim 8. sinıf öğrencilerinin durumluk sürekli kaygı düzeyleri ile sinav kaygısı düzeyleri ve ana-baba tutumları arasındaki ilişkinin incelenmesi (Yüksek Lisans Tezi). Dokuz Eylül Üniversitesi, Eğitim Bilimleri Enstitüsü, İzmir.

Durak, Ö. G., vd. (2018). Lise öğrencilerinde problemli internet kullanımı ile saldırgan davranışların ilişkisi: özel ahmet şimşek anadolu lisesi örneği. Üçüncü Sektör Sosyal Ekonomi, 53(1): 217228. https://doi.org/10.15659/3.sektor-sosyal-ekonomi.18.03.875

Durban, E. F. M. ve Bowlby, J. (1939). Personal aggressiveness and war. New York: Columbia University Press.

Elmas, O., vd. (2015). Teknolojik cihaz kullanım alışkanlıklarının okul başarısı üzerine etkisi. SDÜ Sağlık Bilimleri Enstitüsü Dergisi, 6(2): 49-54.

Ergür, G. (2015). Şiddet içerikli bilgisayar oyunu oynayan ikinci kademe öğrencilerinin saldırganlık eğilimlerinin ve benlik saygı düzeylerinin incelenmesi (Yüksek Lisans Tezi). İstanbul Arel Üniversitesi, Sosyal Bilimler Enstitüsü, İstanbul.

Eroğlu, S. E. (2009). Saldırganlık davranışının boyutları ve ilişkili olduğu faktörler: Lise ve üniversite ögrencileri üzerine karşılaştırmalı bir çalışma (Doktora Tezi). Selçuk Üniversitesi, Sosyal Bilimler Enstitüsü, Konya.

Evcin, S. (2010). Bilgisayar oyunlarının ilköğretim ikinci kademe ögrencilerinin saldırganlık eğilimine etkisinin incelenmesi (Yüksek Lisans Tezi). Maltepe Üniversitesi, Sosyal Bilimler Enstitüsü, İstanbul.

Fan, W., vd. (2011). A multilevel analysis of student perceptions of school climate: The effect of social and academic risk factors. Psychology in the Schools, 48(6): 632-647. https://doi.org/10.1002/pits.20579

Freud, S. (1966). Beyond the pleasure principle. In C. Hubback (Trans.); E., Jones (Ed.). International Psychoanalytical Library, 4, London: International Psycho-Analytical Press, 1-83. https://doi.org/10.1037/11189-001

Fromm, E. (1973). The Anatomy of Human Destructiveness, (3rd ed.). New York: Holt, Rinehart ve Winston Limited.

Fujihara, T., vd. (1999). Justification of 1nterpersonal aggression in Japanese, American, and Spanish students. Aggressive Behavior, 25(3): 185-195. https://doi.org/10.1002/(sici)10982337(1999)25:3<185::aid-ab3>3.0.co;2-k

Gönültaş, O. (2013). Ortaokul son sını öğrencilerinin öfke ve saldırganlık düzeylerinin bazı değişkenlere göre incelenmesi (Yüksek Lisans Tezi). Çukurova Üniversitesi, Sosyal Bilimler Enstitüsü, Adana.

Güçkıran, R. Y. (2008). İlköğretim okulu öğrencilerinin okul iklimi algıları ile saldırganlık düzeyleri arasındaki ilişki (Yüksek Lisans Tezi). Yeditepe Üniversitesi, Sosyal Bilimler Enstitüsü, İstanbul.

Günalan, N. (2018). Ortaokul öğrencilerinin okul yaşam kalitesini, okula aidiyet duygusunu ve okul iklimini neler etkilemektedir? (Yüksek Lisans Tezi). Adnan Menderes Üniversitesi, Sosyal Bilimler Enstitüsü, Aydın.

Günay, G. (2011). Şiddet içerikli online bilgisayar oyunlarının ilköğretim öğrencilerinin saldırganlık tepkileri üzerindeki etkisi (Yüksek Lisans Tezi). Çanakkale 18 Mart Üniversitesi, Sosyal Bilimler Enstitüsü, Çanakkale. 
Gürbüz, S. ve Şahin, F. (2018). Sosyal bilimlerde araştırma yöntemleri (5. Bask1). İstanbul: Seçkin Yayıncilik.

Hartmann, D. P ve Gelfand, D. M. (1969, June). Motivational variables affecting performance of vicariously learned responses. Western Psychological Association, Vancouver.

Hoy, W. K. ve Miskel, C. G. (1987). Educational administration: Theory, research, and practice. New York: Random House.

Hoy, W. K., vd. (1996). The organizational climate of middle schools the development and test of the ocdq-rm. Journal of Educational Administration, 34(1): 41-50. https://doi.org/10.1108/09578239610107156

Hoy, W. K., vd. (1998). Organizational climate and student achievement: A parsimonious and longitudinal view. Journal of School Leadership, 8(4): 336-359. https://doi.org/10.1177/105268469800800401

İli, K. (2013). Sosyal medya ortam ve araçlarının öğrenci davranışlarına etkisi (Gaziçiftliği Anadolu Lisesi örneği) (Yüksek Lisans Tezi). Hacettepe Üniversitesi, Sosyal Bilimler Enstitüsü, Ankara.

İzmir Karaduman, D. (2012). İlköğretim I. kademe 4. ve 5. sınıf öğrencilerinin saldırganlık düzeyleri ile anne baba tutumları arasındaki ilișkinin incelenmesi (Yüksek Lisans Tezi). İstanbul Arel Üniversitesi, Sosyal Bilimler Enstitüsü, İstanbul.

Jia. Y., vd. (2009). The influence of student perceptions of school climate on socioemotional and academic adjustment: A comparison of Chinese and American adolescents. Child Development, 80(5): 1514-1530. https://doi.org/10.1111/j.1467-8624.2009.01348.x

Karasar, N. (2005). Bilimsel araştırma yöntemi. Ankara: Nobel Yayınevi.

Kongur, D. (2015). Illköğretim 6. 7. ve 8. sinıf öğrencilerinin saldırganlık düzeylerinin incelenmesi (Yüksek Lisans Tezi). Beyken Üniversitesi, Sosyal Bilimler Enstitüsü, İstanbul.

Kurt, M. (2010). Yedinci sinı seviye belirleme sinavi matematik ve fen bilimleri alt testlerinin bazı değişkenler açısından incelenmesi (Yüksek Lisans Tezi). Hacettepe Üniversitesi, Sosyal Bilimler Enstitüsü, Ankara.

Lopez, E. E., vd. (2008). Adolescent aggression: Effects of gender and family and school environments. Journal of Adolescence, 31(4): 433-450.

Lorenz, K. (1966). On aggression. London: Methuen.

Lovass, O. I. (1961). Effect of exposure to symbolic aggression on aggressive behavior. Child Development, 32(1): 37-44.

Matuszka, B., vd. (2017). Physical aggression and concurrent alcohol and tobacco use among adolescents. International Journal of Mental Health and Addiction, 15(1): 90-99. https://doi.org/10.1007/s11469-015-9630-6

Milan, S. ve Pinderhughes, E. E. (2006). Family instability and child maladjustment trajectories during elementary school. Journal of Abnormal Child Psychology, 34(1): 40-53. https://doi.org/10.1007/s10802-005-9007-6

Mutluoğlu, S. ve Bulut Serin, N. (2010, Kasım). İlköğretim 5. sınıf öğrencilerinin saldırganlık düzeylerinin bazı sosyo-demografik özellikler açısından incelenmesi (Kuzey Kıbrıs örneklemi). International Conference on New Trends in Education and Their Implications, Antalya-Turkey. 
Nair, B. (2014). Ergenlerin saldırganlık davranışlarının bazı değişkenler açısından incelenmesi (Yüksek Lisans Tezi). Cumhuriyet Üniversitesi, Eğitim Bilimleri Enstitüsü, Sivas.

National School Climate Center. (2014). School climate. Erişim adresi: https://schoolclimate.org/climate.

O'Brien, K. H. M., vd. (2011). School social work practice with students with mental health problems. Children \& Schools, 33(2): 97-105.

Omay, H. (2008). İlköğretim okulları öğrencilerinin okul iklimi algıları ile saldırganlık ölçeği puanları arasındaki ilişkinin incelenmesi (Yüksek Lisans Tezi). Yeditepe Üniversitesi, Sosyal Bilimler Enstitüsü.

Özdemir, Ç. (2016). Sivas ilinde öğrenim gören yabancı uyruklu öğrencilerin okul iklimine etkisine ilişskin görüşlerin incelenmesi (Yüksek Lisans Tezi). Cumhuriyet Üniversitesi, Eğitim Bilimleri Enstitüsü.

Öztürk, H. B. (2014). Aile içi şiddet ve çizgi film izlemenin akademik başarı ve saldırganlıkla ilişskisi (Yüksek Lisans Tezi). İstanbul Sabahattin Zaim Üniversitesi, Sosyal Bilimler Enstitüsü, İstanbul.

Powell, A. ve Jenson, J. M. (2010). Predictors of peer victimization among hispanic adolescent girls: implications for school social work. Children \& Schools, 32(4): 211-222. https://doi.org/10.1093/cs/32.4.211

Santisteban, C., Alvarado, J. M. ve Recio, P. (2007). Evaluation of a spanish version of the Buss and Perry aggression questionnaire: Some personal and situational factors related to the aggression scores of young subjects. Personality and Individual Differences, 42(2007): 1453-1465. https://doi.org/10.1016/j.paid.2006.10.019

Saraç, K. (2015). Okul ikliminin ortaokul öğrencilerinin algılarına göre değerlendirmesi (Yüksek Lisans Tezi). Eskişehir Osmangazi Üniversitesi, Eğitim Bilimleri Enstitüsü, Eskişehir.

School Social Work Association of America. (2012). The role of a school social worker. Erişim adresi: https://docs.wixstatic.com/ugd/426a18_003ab15a5e9246248dff98506e46654b.pdf

Sencer, M. ve Sencer, Y. (1978). Toplumsal araştırmalarda yöntembilim. Ankara: TODAİE.

Sili, A. (2010). Ortä̈ğretim öğrencilerinde saldirganlık ĕgiliminin sosyolojik analizi: Erzurum örneği (Doktora Tezi). Atatürk Üniversitesi, Sosyal Bilimler Enstitüsü, Erzurum.

Şelimen, M. ve Ceylan, H. (2018). Şiddet içeren bilgisayar oyunlarının çocukların saldırganlık davranışı üzerindeki etkileri. Uluslararası Sosyal Araştırmalar Dergisi, 11(60): 668-674. https://doi.org/10.17719/jisr.2018.2820

Tabachnick, B. G. ve Fidell, L. S. (2013). Using multivariate statistics (6th Ed.). Boston: Pearson Education.

Taşçı Eser, D., vd. (2012). Kronik hastalığı olan ergenlerin öfke ifade biçimleri. Psikiyatri Hemşireliği Dergisi, 3(3): 116-120.

Taylan, H. H. (2011). Televizyon programlarındaki şiddetin yetiştirme etkisi: Konya lise öğrencileri üzerine bir araştırma (Yüksek Lisans Tezi). Selçuk Üniversitesi, Sosyal Bilimler Enstitüsü, Konya.

Torun, F., vd. (2015). Analyzing of computer games effects on social life and academic behaviour of the secondary school students. Karaelmas Journal of Educational Sciences, 3(2015): 2535 . 
Torun, Z. B. (2016). Ortaokul öğrencilerinde saldırganlık ve narsisizm düzeyleri arasındaki ilişki (Yüksek Lisans Tezi). Hasan Kalyoncu Üniversitesi, Sosyal Bilimler Enstitüsü, Gaziantep.

Walters, R. H. Ve Willows, D. C. (1968). Imitative behavior of disturbed and nondisturbed children following exposure to aggressive and nonaggressive models. Child Development, 39(1): 7989. https://doi.org/10.2307/1127360

Way, N., vd. (2007). Students' perceptions of school climate during the middle school years: associations with trajectories of psychological and behavioral adjustment. American Journal of Community Psychology, 2007(40): 194-213. https://doi.org/10.1007/s10464-007-9143-y

Yalçın, F. (2015). Çeşitti parametrelerde orta öğretim ögrrencilerinin saldırganlık ve şiddet eğilim düzeylerinin belirlenmesi (Aydın ili İncirliova ilçesi örneği) (Yüksek Lisans Tezi). Gazi Üniversitesi, Eğitim Bilimleri Enstitüsü, Ankara.

Yasankul, N. (2007). İlköğretim 4. ve 5. sinıf öğrencilerinin saldırganlı eğilimleri ile eğitim algıları arasındaki ilişkinin incelenmesi (Yüksek Lisans Tezi). Marmara Üniversitesi, Eğitim Bilimleri Enstitüsü, İstanbul.

Yelci, H. (2018). Ortaokul ögrencilerinde siber zorbalık ile saldırganlık ilişkisinin incelenmesi (Yüksek Lisans Tezi). İstanbul Üniversitesi, Eğitim Bilimleri Enstitüsü, İstanbul.

Yeşilkayalı, E. (2014). Ebeveynlerin çocuk haklarına yönelik tutumları ile ilköğretim ögrencilerinin ahlaki olgunluk ve hoşgörü eğilimleri arasındaki ilişsi (Doktora Tezi). Dokuz Eylül Üniversitesi, Eğitim Bilimleri Enstitüsü, İzmir.

Yıldırım, A., vd. (2011). Lise öğrencilerinin problem çözme becerileri ve etkileyen faktörler. Uluslararası İnsan Bilimleri Dergisi, 8(1): 905-921. https://doi.org/10.17681/hsp.380847 